C O L A B O RA Ç Õ E S ES P E C I A I S

\title{
KARL MARX E A REVOLUÇÃO RUSSA
}

Karl Marx and the Russian Revolution

Carlos Marx y la Revolución Rusa

ANGELO SEGRILLO

http://dx.doi.org/10.1590/S2178-14942017000200010

Angelo Segrillo é mestre em Língua e Literatura Russa pelo Instituto Pushkin de Moscou, doutor em História pela Universidade Federal Fluminense e professor livre docente na Universidade de São Paulo (angelosegrillo@yahoo.com).

Artigo recebido em 31 de janeiro e aprovado para publicação em 26 de abril de 2017. 


\title{
RESUMO
}

O artigo analisa a visão de Karl Marx sobre a possibilidade de ocorrência da revolução na Rússia. Inicialmente concentrando suas esperanças nos países da Europa Ocidental, onde o capitalismo estava mais desenvolvido, com o fracasso das revoluções de 1948 e da Comuna de Paris, Marx se volta para as possibilidades de revolução a partir do Leste, da Rússia, até ali considerada o bastião da reação. Suas ideias são expostas em correspondência com os próprios revolucionários russos. Essa trajetória intelectual de Marx é descrita a partir de seus próprios escritos.

PalaVras-CHAVE: Karl Marx, Rússia, revolução, Revolução Russa.

\begin{abstract}
This article analyzes Marx's vision about the possibility of revolutionary outbreaks in Russia. His initial hopes were concentrated on the countries of Western Europe, where capitalism was more highly developed. With the defeat of the 1848 revolutions and of the Paris Commune, Marx turns his attention to the possibility of a revolution coming from the East, from Russia, until then considered a bastion of reaction. His ideas are exposed in an exchange of letters with the Russian revolutionaries themselves. Marx's intellectual development on this issue is described using his own writings as a basis.
\end{abstract}

KeYwOrDs: Karl Marx, Russia, revolution, Russian Revolution.

\section{RESUMEN}

El artículo analiza la visión de Karl Marx sobre la posibilidad de eclosión de la revolución en Rusia. Sus esperanzas iniciales se concentraron en los países de Europa Occidental, donde el capitalismo estaba más desarrollado. Con la derrota de las revoluciones de 1848 y de la Comuna de París, Marx vuelve su atención a la posibilidad de una revolución procedente del Oriente, de Rusia, hasta entonces considerada un bastión de reacción. Sus ideas están expuestas en correspondencia con los revolucionarios rusos. El desarrollo intelectual de Marx sobre esta cuestión se describe utilizando sus propios escritos como base.

Palabras Clave: Karl Marx, Rusia, revolución, Revolución Rusa. 


\section{INTRODUÇÃO}

Zarl Marx e a Revolução Russa! É uma combinação de duas expressões que tendemos La receber de forma natural e até como intrinsecamente imbricadas entre si, já que a revolução bolchevique foi realizada em nome dos ideais e da teoria de Marx. 0 marxismo foi a ideologia motora da União Soviética em todos os seus anos de existência. Tanto que muitos críticos de Marx o culpam pelos próprios resultados negativos da Revolução Russa, apesar de o filósofo alemão já não estar vivo em 1917. Em relação a esse ponto, uma das maneiras de abordar a relação entre Marx e a Revolução Russa é ver o quanto os atores e pensadores da Revolução Russa realmente refletiam as ideias de Marx. Neste artigo, estaremos analisando a relação em sentido contrário: em que medida Marx, em seu tempo de vida, via a possibilidade de a revolução ocorrer na Rússia. Afinal, Marx estudava a possibilidade de eclosão de uma revolução socialista que viria a resolver as contradições do capitalismo. Se a Rússia, na maior parte da vida de Marx, era um país onde ainda existia a servidão (feudalismo, diriam controvertidamente alguns), seria possivel ocorrer tal tipo de revolução lá?

Veremos que a atitude de Marx em torno da questão se modificou ao longo da vida e está muito imbricada com a maneira como o Mouro ${ }^{1}$ via a Rússia de maneira geral. Grosso modo, podemos distinguir duas grandes fases gerais com um longo período de transição entre elas. Na parte inicial de sua carreira intelectual, Marx tendia a ver a Rússia como o bastião da reação, o país que poderia impedir a revolução progressista na Europa: seu grande modelo histórico foi o papel da Rússia na derrota de Napoleão, encurralando os ideais revolucionários franceses de 1789/1793. Com a derrota das revoluções de 1848 e da Comuna de Paris de 1871 na Europa Ocidental, nos anos finais de sua vida, o Mouro passou a dedicar uma atenção cada vez mais forte ao potencial revolucionário dos desenvolvimentos na Rússia. 0 período de transição entre as duas fases se refere ao fato de que o envolvimento de Marx com os próprios revolucionários russos para um aprofundamento de seus conhecimentos do país já se iniciara antes. Marx publicara o volume I de 0 Capital em 1867 e, ironicamente, a primeira tradução em língua estrangeira se daria na... Rússia! A tradução russa seria publicada em 1872, mas desde 1868 o tradutor, Nikolai Danielson, se engajou em forte correspondência com Marx na qual não apenas tirou dúvidas da tradução, 
mas também enviou a Marx grandes volumes de estatísticas sobre a Rússia que serviriam para que o Mouro pudesse aprofundar seus próprios estudos sobre aquele país eslavo. Marx inclusive aprenderia russo para poder trabalhar essas fontes primárias na língua original. A ironia desse momento de transição, quando o Mouro passou a escrever sobre a Rússia não mais "de fora" (com fontes secundárias ocidentais) e sim "de dentro" (a partir de fontes primárias russas na língua original), se deu também pelo fato de que o contato de maior relevo inicial de Marx com os revolucionários russos se passou mais com os narodniki ("populistas") que com os próprios marxistas russos de então (que inclusive eram adversários da ideologia narodnik). Além disso, dentro dessa fase "de transição", devemos notar o ponto de viragem do período de repensar na Rússia após a Guerra da Crimeia (1853-1856) que desaguaria na abolição da servidão no país em 1861, a partir do qual Marx começou a aventar a possibilidade de a Rússia ter potencial revolucionário pelo menos dentro do quadro de uma revolução europeia ou mundial mais ampla. ${ }^{2}$

Vejamos por partes o desenrolar de todo esse percurso intelectual tortuoso e repleto de surpresas irônicas que foi a relação de Marx com a Rússia e com as possibilidades revolucionárias daquele país.

\section{PRimeiros ESCRITOS}

Q uando Marx teve aprovada sua tese doutoral sobre as diferenças entre as filosofias de Epicuro e Demócrito em 1841 e iniciou sua vida profissional obtendo o cargo de redator-chefe do jornal Gazeta Renana no ano seguinte, ele ainda não era comunista. Era um democrata algo à esquerda dos liberais da época, herança de sua pertença ao campo dos hegelianos de esquerda na universidade. Somente se assumiria como comunista em 1844, época de sua mudança para Paris. É importante notar esse efeito "França" na passagem de Marx ao comunismo, pois ele teria consequências em suas futuras atitudes em relação à Rússia. $A$ convivência direta e os debates com correntes radicais ainda marcadas pelos efeitos da Revolução Francesa (blanquistas, neojacobinos, etc.) impregnaria a imaginação política de Marx. 0 modelo da Revolução Francesa seria a principal matriz da qual o Mouro extrairia paradigmas para futuras possíveis revoluções socialistas. E nesse modelo da Revolução Francesa histórica, a Rússia teve o papel de cidadela principal da reação que, ao final das contas, possibilitaria a contrarrevolução. E a experiência, na sequência, das revoluções de 1848, em que a Rússia foi um dos poucos países que passou incólume, sem revoltas, pelo período (e ainda ajudou a derrotar levantes na Europa Oriental, como na Hungria e Valáquia), fortaleceu ainda mais essa impressão marxiana. Assim, no período inicial de suas atividades revolucionárias, o Mouro via 
a Rússia como o grande inimigo potencial da futura revolução socialista que ele esperava ver ocorrer na Europa Ocidental.

A antipatia de Marx pela Rússia teve também conotações pessoais logo no seu início. O fim da primeira experiência jornalística do Mouro, na Gazeta Renana, teve ligação direta com o czar russo. 0 jornal publicou, em 4 de janeiro de 1843, um artigo violento em que acusava a Prússia de ser tutelada pela Rússia em sua política externa. Como esse artigo vinha na esteira de outros de cunho antirrusso, o czar Nicolau I exigiu do rei da Prússia que a Gazeta Renana fosse punida. Como já estava às turras com o radicalismo do jornal, o governo prussiano ordenou o seu fechamento.

Essa experiência fortaleceria a impressão inicial de Marx de que a Rússia agia, diretamente ou por trás dos bastidores, para minar os progressos liberais na Europa (relembremos que nem estamos falando de revolução socialista nesse momento, já que em 1843, como vimos, o Mouro ainda não era comunista, mas apenas um democrata radical).

Quando Marx se tornou comunista em 1844, suas primeiras preocupações estavam voltadas mais para os países da Europa Ocidental. Ele explorava em especial a possibilidade de a revolução eclodir a partir da França. E foi, mais ou menos, o que ocorreu em 1848. A revolução de Fevereiro na França iria catalisar impulsos iniciais já existentes e potenciar a disseminação dos levantes pela Europa. Entretanto, novamente a Rússia teria neles um papel reacionário. Um dos poucos países não afetados (praticamente falando) pelas revoltas daquele ano, seus exércitos (repetindo a experiência histórica do período napoleônico) esmagariam a revolução em terras estrangeiras, como na Hungria e Valáquia. Foi nessa época que Marx e Engels trataram do problema do pan-eslavismo, a doutrina que pregava a união dos povos eslavos, mas que, na sua versão russa, pretendia que tal união se fizesse tendo como base a maior dessas nacionalidades eslavas (ou seja, a russa). Os dois fundadores do marxismo viam essa ideologia como reacionária na escala da revolução mundial. Sobre essa ideologia especificamente, Engels seria o mais prolífico na escrita. No artigo "Pan-eslavismo democrático" (publicado na Nova Gazeta Renana em fevereiro de 1849), ele criticaria até as tendências pan-eslavistas (ditas democráticas) de aliados de esquerda, como Bakunin. A radicalidade desse artigo tocava no polêmico conceito dos "pequenos povos sem futuro", no trecho em que Engels diz: "Nós repetimos: fora os polacos, russos e, no máximo, os eslavos turcos, nenhum outro povo eslavo tem futuro pela simples razão que a todos os outros eslavos faltam as condições básicas históricas, geográficas, políticas e industriais para a independência e viabilidade" (MEW, vol. 6, p. 275).

A condição da Rússia como país "semifeudal" (somente em 1861 seria lá abolida a servidão) fazia a Rússia duplamente reacionária na visão de Marx de então. Ela seria 
reacionária não só a uma futura revolução socialista, mas também até a uma mera revolução burguesa em países (como a Alemanha) que não tinham ainda tido sua revolução burguesa completada. É importante sublinhar essa situação da Alemanha como país onde a revolução burguesa não tinha sido completada (até a época sobre a qual estamos falando de 1848), pois quando estivermos discutindo a parte final da vida de Marx, quando ele vai considerar seriamente a possibilidade de a revolução eclodir na Rússia, teremos que diferenciar bem a que tipo de revolução estaremos nos referindo: uma revolução socialista ou uma revolução burguesa na Rússia?

\section{A Guerra dA CRIMEIA (1853-1856)}

$\mathrm{O}$ ponto acima veremos posteriormente, quando chegarmos nessa fase final da vida de Marx. Por enquanto, devemos notar que, após o "fracasso" das revoluções de 1848, o outro grande marco que novamente aglutinaria a atenção de Marx em relação à Rússia seria a Guerra da Crimeia (1853-1856). Nela, os russos se defrontariam com os turcos otomanos auxiliados pelos ingleses e franceses. Nessa época, Marx, expulso de todos os países europeus continentais nos quais viveu durante o período das revoluções de 1848, já tinha chegado ao seu exílio final definitivo na Inglaterra, onde residiria o resto de sua vida. De 1851 a 1862, escreveria artigos sobre política internacional para o jornal progressista norte-americano New York Daily Tribune. Seria no quadro desses artigos que Marx faria suas análises da Guerra da Crimeia.

De maneira geral, durante a guerra, Marx manteria sua linha anterior sobre a Rússia como cidadela da reação, com palavras de precaução contra o pan-eslavismo. Os artigos durante a guerra em si não contêm nada de muito novo em relação à posição de Marx vis-à-vis a Rússia em comparação ao período anterior. Mas logo depois do final da guerra interessantes desenvolvimentos nesse sentido teriam lugar.

Antes de tudo, uma explicação preliminar. Mencionamos anteriormente que, em seu período inicial, até as revoluções de 1848, Marx tendia a procurar a revolução na Europa Ocidental, onde o capitalismo estava mais desenvolvido, e relegava a "semifeudal" Rússia ao papel de fortaleza da reação. Dentro dessa visão de procurar a revolução socialista onde o capitalismo estava mais desenvolvido (e, portanto, também mais cheio de contradições), alguém poderia imaginar que Marx, então, colocaria num papel central a Inglaterra, o país de capitalismo mais desenvolvido então. Mas não era assim. Já vimos que Marx considerava ainda a França em 1848 o país com maior potencial de revolução. Curiosamente, Marx (novamente seguindo o paradigma da Revolução Francesa de 1789/1793) considerava que 0 
potencial revolucionário centrado na França era sufocado de um lado pela "atrasada" Rússia (fortaleza da reação contra quaisquer revoluções, burguesa ou socialista) e de outro pela "adiantada" Inglaterra (cujo capitalismo forte seria a cidadela burguesa da reação contra a futura revolução socialista). Essa "russofobia" de Marx está mais ou menos clara. Mas a "anglofobia" se formou de maneira mais sutil e com alguns requintes de insólito, culminando na aproximação de Marx com o excêntrico diplomata e parlamentar escocês David Urquhart. Urquhart suspeitava que Lord Palmerston (que ocupou cargos como ministro do Exterior em 1835-1841 e 1846-1851, ministro do Interior em 1852-1855 e primeiro-ministro em 18551865 no Reino Unido) fosse, na verdade, um agente da política externa russa. Marx, que já tinha sua visão de que a Inglaterra e a Rússia tinham a tendência a se unir contra a Revolução (como fizeram com Napoleão), ao se aproximar de Urquhart passou a investigar tal hipótese. 0 resultado de tais investigações seria exposto numa série de artigos no New York Daily Tribune e em The People's Charter em 1853 e 1854, publicados depois como brochura em separado intitulada Lord Palmerston (MEW, vol. 9, p. 353-418). Após essa investigação inicial centrada na figura de Palmerston, Marx planejava iniciar uma pesquisa maior sobre os subterrâneos da diplomacia europeia entre Inglaterra e Rússia. Entretanto, esta quedaria inconclusa, tendo o Mouro terminado apenas sua introdução, que foi publicada em 1856-1857 de forma seriada no semanário urquhartista The Free Press com o título Revelações da História Diplomática do Século XVIII (MECW, vol. 15, p. 25-96). Em um trabalho posterior, Herr Vogt, o próprio Marx explicaria assim o conteúdo de todas essas démarches na história diplomática anglo-russa:

Eu estava excitado, mas não convencido, pelos escritos de Urquhart sobre a Rússia e contra Palmerston. Com o fito de chegar a um ponto de vista definitivo, fiz um estudo fino e cuidadoso dos Debates Parlamentares de Hansard e dos Livros Azuis diplomáticos de 1807 a 1850. 0 primeiro resultado desses estudos foi uma série de artigos no New York Tribune no final de 1853 em que demonstrei as ligações de Palmerston com os ministros em São Petersburgo em relação às transações com a Polônia, Turquia, Circassia, etc. [... . Ao pesquisar nos manuscritos diplomáticos do Museu Britânico, encontrei uma série de documentos ingleses que iam do final do século XVIII à época de Pedro, o Grande, que revelavam a secreta e permanente cooperação entre os ministros de Londres e São Petersburgo e que essa colaboração provinha da época de Pedro, o Grande. Eu quero devotar um estudo detalhado a esse assunto, do qual até agora só publiquei a introdução sob o título Revelações da História Diplomática do Século XVIII (MEW, vol. 14, p. 474).

Temos aí um Marx não somente fazendo (pouco caracteristicamente) um estudo da superestrutura diplomática (em vez da sua tradicional ênfase na infraestrutura econômica), mas também com requintes de suspense de revelações "secretas"! Na verdade, as duas obras, 
especialmente a última, serviram como base para Marx se aprofundar um pouco mais na história da Rússia, mesmo que baseado em fontes "secundárias" (inglesas) e sem ter como resultado modificações sensíveis na posição que vinha mantendo sobre a Rússia até ali. Muito cruamente colocado, a Rússia continuava sendo a cidadela da reação no imaginário marxiano. Inclusive a ponto de o Mouro considerar que uma guerra com a Rússia seria inevitável caso a revolução eclodisse no Ocidente para evitar que o gigante eslavo de novo trouxesse a reação e assegurasse a vitória da contrarrevolução, como nos tempos napoleônicos. Como colocou Marx em seu artigo publicado em 12/08/1853 no New York Daily Tribune sobre a Guerra da Crimeia:

Constantinopla é a ponte dourada entre o Ocidente e o Oriente. A civilização ocidental, como o sol, não pode dar a volta ao mundo sem passar por essa ponte; e não pode passá-la sem uma batalha com a Rússia. 0 sultão mantém Constantinopla apenas em confiança para a Revolução [...] A Revolução que destruirá a Roma do Ocidente também vencerá as influências demoníacas da Roma do Oriente (MEW, vol. 9, p. 236-237).

\section{O PÓS-GUERRA DA CRIMEIA RUMO À ABOLIÇÃO DA SERVIDÃO EM 1861: PRIMEIRAS INFLEXÕES SENSÍVEIS DE MARX EM RELAÇÃO À RÚSSIA}

A Guerra da Crimeia produziu sequelas profundas na sociedade russa. A constatação da Revolução Industrial) sobre a ainda "semifeudal" Rússia deixou os russos perplexos. Grandes debates se fizeram no país em relação à servidão. Considerada por muitos o fator que atrasava o desenvolvimento do capitalismo na Rússia, a questão da emancipação dos servos se tornou o grande ponto de discussão nos anos seguintes. Desde a mensagem do czar Alexandre II aos representantes da nobreza de Moscou em 30 de março de 1856 (em que dizia que "o sistema existente de servidão não pode continuar como está. É melhor começar a abolir a servidão de cima do que esperar que ela comece a ser abolida de baixo. Eu lhes peço, senhores, que comecem a pensar em maneiras de como fazê-lo") até a finalização do definitivo Manifesto de Emancipação de 19 de fevereiro de 1861, a Rússia passou por acaloradas e tensas negociações em diversos níveis sobre como conduzir esse processo.

0 alto nível da tensão social no país ao longo desse tempo, com o medo das elites de ocorrência de revoltas camponesas em larga escala, chamou a atenção de Marx. Ele percebia que um ponto de viragem estava para ocorrer, a partir do qual o país não seria mais 0 
mesmo. A abolição da servidão significaria a possibilidade de a Rússia deixar para trás seus resquícios feudais e entrar plenamente em um regime capitalista. Tudo isso levava, no mínimo, à possibilidade de ocorrência de uma revolução burguesa na Rússia. Temos aí o primeiro grande momento de inflexão de Marx sobre a Rússia. Até então, ela era considerada por ele apenas como a "cidadela da reação" antirrevolucionária. Agora ele passaria a considerar a possibilidade de uma revolução acontecer também ali. Como colocou em sua carta a Engels de 13 de dezembro de 1859, " [na] Rússia o movimento está se desenvolvendo mais rápido que no resto da Europa [...] Quando a próxima revolução eclodir, a Rússia gentilmente se revolucionará também" (MEW, vol. 29, p. 525). 0 contraste apontado por Marx se refere ao fato de que após os grandes abalos revolucionários de 1848, a década de 1850 (até pela fase de prosperidade econômica) se revelou excessivamente "calma" na Europa Ocidental, estagnada do ponto de vista das possibilidades revolucionárias. As efervescências do período das discussões pré-abolição da servidão na Rússia abriram os olhos de Marx para possibilidades revolucionárias mais a leste.

No entanto, como mencionamos, esse foi o início de uma longa fase intermediária de transição. Não se deve imaginar que Marx rompeu totalmente com suas concepções passadas. Na verdade, elas continuaram paralelamente aos novos desenvolvimentos. Marx ainda via a Rússia como basicamente uma cidadela da reação, mas admitia a possibilidade de que uma revolução pudesse também ocorrer a partir das insatisfações vindas do campo. Inclusive, como vimos na citação acima, tendia a ver uma possível revolução na Rússia ocorrendo concomitantemente a uma revolução na Europa Ocidental. A possibilidade de uma revolução burguesa autônoma na Rússia não estava descartada, mas ele via mais a possibilidade de o campo russo forçar alterações qualitativas no país aproveitando a força de impulsos concomitantes vindos do Ocidente. Mas essas eram apenas possibilidades alternativas. 0 cenário de "fortaleza da reação" prosseguia na mente de Marx.

Não só prosseguia na mente de Marx, como voltaria a se robustecer durante a década de 1860, quando nem aconteceu a revolução no Ocidente, nem os esperados abalos sísmicos na Rússia a partir da questão da abolição da servidão chegaram a se concretizar. Tanto que, por exemplo, a malograda revolta polonesa de 1863 (contra o então domínio russo sobre o país) serviu para Marx desencadear escritos em que retomava sua tradicional posição antirrussa. O Mouro redigiu para a Sociedade Educacional de Trabalhadores Alemães em Londres, uma Proclamação Sobre a Polônia que declarava que:

A questão polonesa é a questão alemã. Sem uma Polônia independente não pode haver uma Alemanha independente e unida, uma Alemanha emancipada do domínio russo [...] A 
aristocracia alemã há muito tempo reconhece o czar como seu soberano supremo secreto. A burguesia alemã olha, silenciosa, passiva e indiferente, o massacre da nação heroica, única a proteger a Alemanha do dilúvio moscovita [...] e vê a autocracia no Leste como o reino do golpe de estado no Ocidente, ou seja, como um pilar necessário da ordem [vigente] (MECW, vol. 19, p. 296-297).

Anos depois, em um discurso em 22 de janeiro de 1867, por ocasião do aniversário da revolta polonesa de janeiro de 1863, Marx seria ainda mais brutal em relação à Rússia:

Eu lhes pergunto? 0 que mudou? 0 perigo russo diminuiu? Não. Na verdade, a ilusão das classes dominantes da Europa chegou ao ápice. Afinal, nada mudou na política russa, como seu historiador oficial, Karamzin, admite. Seus métodos, suas táticas, suas manobras podem mudar, mas sua estrela guia - a dominação mundial - continua a mesma (MEW, vol. 16, p. 202).

\section{SEGUNDO GRANDE ELEMENTO DA FASE DE TRANSIÇÃO: A CORRESPONDÊNCIA COM OS POPULISTAS RUSSOS E O ESTUDO DE FONTES PRIMÁRIAS RUSSAS}

omo vimos acima, o período pós-Guerra da Crimeia e pré-abolição da servidão na
Rússia introduziu uma inflexão inicial (a aceitação de uma possibilidade revolucionária na própria Rússia) que acabou não se concretizando, propiciando assim uma volta do discurso inicial marxiano sobre aquele país eslavo. Entretanto, um segundo momento de inflexão, dentro dessa fase intermediária de transição do pensamento de Marx sobre a Rússia, surgiria quando, ironicamente, a Rússia foi o país onde mais imediatamente se deu uma resposta positiva para a publicação do volume I de O Capitalem 1867. Enquanto nos países ocidentais a resposta imediata ao livro, em termos de público geral e crítica especializada, foi morna (levando, inclusive, Engels a escrever, sob pseudônimo, várias resenhas, positivas e negativas, sobre o livro a fim de despertar atenção sobre ele), na Rússia a obra foi alvo de interesse a ponto de, no ano seguinte, já ser iniciada lá a primeira tradução de O Capita/para uma língua estrangeira. ${ }^{3}$

A correspondência que iniciou com o tradutor da obra, o economista russo simpatizante dos narodniki ("populistas"), Nikolai Danielson, para tirar dúvidas de tradução, se tornaria, por outro lado, um canal para Marx receber, pelo correio, uma imensa quantidade de material sobre a economia e sociedade russas, sobre o qual se debruçou com avidez. Mais ainda, Marx passou a estudar russo para poder, dali em diante, estudar o país a partir de suas fontes primárias na língua original. ${ }^{4}$ 
Tal foi o segundo ponto de viragem nessa fase de transição de Marx para a Rússia. Ele entraria na década de 1870 estudando a Rússia a partir das fontes primárias locais na língua original em contato direto maior com revolucionários e intelectuais russos dentro do próprio país. Em 1870, a pedido dos socialistas russos exilados em Genebra, Marx se tornou o representante da seção russa no Conselho Geral da Associação Internacional dos Trabalhadores (a chamada Primeira Internacional).

\section{A fase finAl DAS POSIÇÕES DE MARX SObRE A RÚSSIA}

destruição da Comuna de Paris em 1871, repetindo o "fracasso" das tentativas revolu-
cionárias de 1848 na Europa Ocidental, aprofundaria ainda mais essa virada de Marx para o leste. No caso da Rússia, havia agora uma grande ambiguidade. Desde que a servidão fora lá abolida em 1861, os entraves "feudais" para o desenvolvimento do capitalismo tinham sido erradicados. Caso a Rússia estivesse realmente no caminho capitalista, isso significaria que seria possível uma revolução socialista lá? Marx estava consciente do grande hiato, na Rússia, entre as classes dirigentes, que procuravam mantê-la como a "fortaleza da reação", e a efervescência nas classes baixas, onde a problemática abolição da servidão, em vez de acalmar os ânimos, insuflara demandas por melhorias nas insuficiências do sistema. Com a dificuldade da eclosão da revolução no Ocidente, Marx acompanhava os processos na Rússia com esperança. Por ocasião da Guerra Russo-Turca de 1877, escreveu a Friedrich Sorge, em 27/09/1877:

A Rússia há muito se encontra no limiar de uma revolução. Todos os elementos estão prontos para isso. Eu tenho estudado sua condição através de fontes originais russas, não oficiais e oficiais (as últimas são disponíveis apenas a poucos, mas as consegui através de alguns amigos em São Petersburgo) [...] A Revolução desta vez começará no Leste, que até agora era a fortaleza e o exército de reserva da contrarrevolução (MEW, vol. 34, p. 296).

Com o aprofundamento de seu conhecimento sobre a Rússia, o Mouro passou a tomar parte nas discussões das características muito especificamente russas daquela formação social. Uma questão fulcral era a da chamada "comuna rural" russa. Ao contrário do Ocidente, com sua agricultura de propriedade privada, na Rússia, mesmo depois da abolição da servidão, os camponeses tinham a terra não em regime de propriedade privada individual, mas coletivamente, na chamada "comuna rural". Por exemplo, com a abolição da servidão, a comunidade de camponeses que trabalhavam para um mesmo senhor recebeu (mediante pagamento em 40 anos) parte das terras do senhor para que agora, sem servidão, pudessem usá-las para si. 
Mas as terras não eram dadas como propriedade privada individual inalienável. 0 conjunto de camponeses recebia o total de terras, dividia-o entre seus membros, e os assuntos comuns eram por eles tratados na assembleia da comuna. Entretanto, como as famílias cresciam com seus descendentes, a terra sofria repartições periódicas para que todos (inclusive os das novas gerações) pudessem ter acesso ao seu lote. Ora, esse era um arranjo que tinha características de comunismo: a propriedade vista mais como comunal que privada, assembleias onde as questões da comunidade eram resolvidas pelos seus membros, etc.

Na segunda metade do século XIX, na Rússia, haveria um debate entre populistas (narodniki) e marxistas sobre a instituição da comuna rural. Os narodniki achavam que a Rússia poderia passar ao largo do capitalismo e dar um pulo para um socialismo agrário utilizando a comuna rural como plataforma. Já os marxistas achavam que, com a abolição da servidão, a Rússia já tinha ingressado na estrada do capitalismo e que a comuna rural (como um resquício de séculos passados) seria varrida pelo desenvolvimento capitalista: a solução seria lutar por um socialismo com base industrial.

0 debate atingiria Marx em cheio em sua década final de vida. E, por incrível que pareça, muitas vezes ele parecia simpatizar mais com os populistas! Danielson, o economista tradutor de 0 Capital para a língua russa, era simpatizante dos populistas. Na verdade, 0 populismo surgiu antes do marxismo na Rússia (então engatinhando durante a vida de Marx) e, por isso, não admira que Marx tenha tido mais contato com eles do que seus (ainda pouco numerosos) discípulos na Rússia.

Essa situação irônica ficaria marcada no episódio quase final da vida de Marx e que mais ficou ligado, para as futuras gerações, com a questão da viabilidade ou não de uma revolução socialista na Rússia: a resposta de Marx à famosa carta de Vera Zasulitch com a pergunta sobre a possibilidade de uma revolução na Rússia utilizando a comuna rural como base do desenvolvimento socialista.

As circunstâncias que rodearam a carta põem em relevo a complexidade irônica das relações Marx/Rússia/populistas/marxistas. Quando Vera escreveu a carta em 16 de fevereiro de 1881, ela fazia parte de um grupo de populistas que, perseguidos na Rússia, haviam se refugiado em Genebra, na Suiça. Os mais famosos do grupo seriam, além de Vera, Georgui Plekhanov, Pavel Axelrod e Lev Deutsche. A ironia é que quando Vera escreveu a carta em nome do grupo, eles eram ainda populistas. Dois anos depois, em 1883, ainda no exílio em Genebra, fundariam a primeira organização marxista russa, o grupo Emancipação do Trabalho, abandonando suas posições populistas originais de quando eram membros da Repartição Negra (uma das duas alas em que se dividiu a organização populista Terra e Liberdade, na Rússia). Na verdade, essa transição, na época, parecia menos radical do que parece hoje, já que o 
populismo (narodnichestvo) era então um grande guarda-chuva que até o final da década de 1870 abrangeu um amplo leque da esquerda, enquanto o marxismo (ou os marxistas) propriamente dito estava apenas começando a se desenvolver na Rússia nos anos 1880. Como vimos pela correspondência do próprio Marx com os populistas russos (Danielson, Lavrov, etc.), havia uma grande sobreposição e intercâmbio entre esses espectros da esquerda socialista.

Foi nessa zona ainda de penumbra que a carta de Vera Zasulitch chegou a Marx em Londres. A pergunta era clara: a comuna rural russa poderia servir de base para um futuro desenvolvimento socialista no país (como queriam os populistas) ou estava fadada a desaparecer com o desenvolvimento do capitalismo no país, e portanto não adiantava insistir com ela na luta socialista (como queriam os marxistas russos)?

Poder-se-ia esperar que Marx concordasse imediatamente com os "marxistas" russos, mas não foi isso que aconteceu. O Mouro pareceu vacilar. Escreveu quatro longos rascunhos de sua resposta (o primeiro com aproximadamente 4.500 palavras, o segundo e o terceiro com 2.000, o quarto com 300) e, no final, acabou enviando apenas uma carta sucinta em 8 de março de 1881 (com 350 palavras). Ou seja, levou quase dois meses para responder e veremos o porquê de suas dúvidas e vacilações. 0 próprio Marx não tinha certeza!

Quem já leu o Manifesto Comunista, que menciona a "idiotice da vida rural" (MEW, vol. 4, p. 466), sabe que Marx nunca teve ilusões idílicas sobre a vida no campo. Por que, então, no caso da Rússia, estava tão em dúvida sobre a comuna rural em vez de dar logo uma resposta negativa?

Uma parte da explicação é o próprio fato da sua grande correspondência com autores populistas. Os narodniki enfatizavam o trabalho com os camponeses e consultavam os autores russos que mais escreviam sobre a instituição da comuna rural. Os que mais escreviam sobre a comuna rural eram os chamados eslavófilos. As reformas modernizantes ocidentalizantes de Pedro, o Grande, no início do século XVIII haviam rachado a sociedade russa. Os que, como Pedro, achavam que a Rússia era parte da Europa e deveria, assim, seguir o modelo de desenvolvimento ocidental, constituíam o grupo dos ocidentalistas. Já os eslavófilos eram aqueles que achavam que Pedro tinha descaracterizado o modo de vida tradicional russo, que a Rússia não era nem Europa nem Ásia e sim uma civilização única e, portanto, deveria seguir caminho próprio, sem imitar os ocidentais. A sociedade russa no século XIX rachou sobre essa questão. Os eslavófilos tendiam a idealizar o modo antigo de vida russo que, no campo, incluía a comuna rural. Por isso, vários eslavófilos (e.g., Aleksandr Koshlev) destacavam-se entre os que publicavam estudos históricos sobre a comuna rural (no caso deles, sempre de um ponto de vista positivo). E Marx os lia! Além disso, Marx admirava os escritos econômicos de Nikolai Tchernichevski (um dos ídolos dos populistas). 
Tudo isso parece fazer parte de um movimento alternativo de Marx desde que a revolução tinha falhado em eclodir no Ocidente em 1848 e 1871. Combinado com a abolição da servidão na Rússia, que criava um quadro novo, com o abandono das formas feudais e a adoção das capitalistas, criaram-se novas possibilidades naquele país eslavo. Combinado, ainda mais, com a existência da comuna rural, serviria ela de plataforma para o lançamento de possibilidades revolucionárias socialistas?

Marx refletiu muito antes de responder à questão de Zasulitch sobre a comuna rural russa. Pelos rascunhos sucessivos que fez, podemos ver que começou bem aberto a uma resposta positiva para, no final, dar uma resposta sucinta e ambígua. É importante notar essa evolução, pois a maioria dos autores que veem na resposta de Marx a Vera Zasulitch uma mudança definitiva para o ponto de vista de que a revolução era possível na Rússia, com participação positiva da comuna rural, utiliza trechos do texto dos rascunhos da resposta de Marx (ao passo que a carta-resposta em si é bem menos decidida nesse ponto).

Tomemos trechos do primeiro rascunho de resposta de Marx (o mais longo de todos, com tantas páginas que parecia um pequeno ensaio) para podermos notar quão perto de uma resposta positiva esteve Marx.

[Em O Capital] Discutindo a gênese da produção capitalista, eu disse que o segredo é que há, no fundo, "uma completa separação do produtor dos meios de produção" [...] e que "a expropriação do produtor agrícola é a base de todo o processo. Somente na Inglaterra isso foi conseguido de maneira radical [,mas] os outros países da Europa Ocidental estão seguindo o mesmo curso" [...] Assim, eu expressamente restringi a "inevitabilidade histórica" desse processo aos países da Europa Ocidental [...] Em última análise, então, uma forma de propriedade privada é transformada em outra forma de propriedade privada (o caminho ocidental). Como as terras dos camponeses na Rússia nunca foram sua propriedade privada, como essa tendência poderia ser aplicada a elas? [...] De um ponto de vista histórico, somente um argumento sério foi dado para a dissolução inevitável da comuna rural russa: diz-se que, se nós formos atrás no tempo, tipos mais ou menos arcaicos de propriedade comunal podem ser encontrados na Europa Ocidental. Mas, com o progresso da sociedade, desapareceram em toda parte. Por que somente na Rússia haveriam de escapar desse destino? Minha resposta é que, graças à combinação única de circunstâncias na Rússia, a comuna rural, que ainda está estabelecida em escala nacional, pode gradualmente se livrar de suas características primitivas e se desenvolver diretamente como um elemento de produção coletiva em escala nacional. Precisamente por que ela é contemporânea com a produção capitalista, a comuna rural pode se apropriar de suas realizações positivas sem passar por suas terríveis vicissitudes. A Rússia não vive em isolamento do mundo moderno e nem caiu vítima de uma potência conquistadora estrangeira, como as Índias Orientais. Se os admiradores russos do sistema capitalista negam que tal desenvolvimento seja teoricamente possível, então eu lhes faço 
a seguinte pergunta. A Rússia teve que passar por uma incubação da indústria mecânica do tipo ocidental antes de ela começar a fazer uso de maquinaria, navios a vapor, ferrovias, etc.? Que expliquem também como ela conseguiu introduzir, num piscar de olhos, toda a aparelhagem de intercâmbio (bancos, companhias de crédito, etc.) que foi resultado de séculos de trabalho no Ocidente. Se na época da abolição da servidão, a comuna rural tivesse sido colocada inicialmente em condições normais de prosperidade e se, além disso, o imenso débito público (financiado à custa dos camponeses) juntamente com as enormes quantias que o Estado (novamente à custa dos camponeses) forneceu aos "novos pilares da sociedade" (os capitalistas) tivessem servido para o desenvolvimento da comuna rural, ninguém estaria hoje sonhando com a "inevitabilidade histórica" do desaparecimento da comuna. Todos veriam a comuna como o elemento de regeneração da sociedade russa e um elemento de superioridade sobre os outros países ainda escravizados pelo regime capitalista [...] A comuna pode gradualmente substituir a agricultura fragmentada pela agricultura mecanizada de larga escala, que é particularmente propícia para a configuração física da Rússia. Ela pode ser, então, o ponto de partida direto para o sistema econômico ao qual a sociedade moderna tende (Sochineniya, vol. 19, p. 400-406)

Como vemos, no primeiro rascunho de carta (com muitas páginas, um verdadeiro ensaio) Marx chegou perto de simplesmente dar uma resposta positiva à indagação de Zasulitch dizendo que não só a comuna rural russa poderá sobreviver, como poderá até ser o "ponto de partida para o sistema ao qual a sociedade moderna tende", isto é, o socialismo. Mas este entusiasmo inicial vai se arrefecendo um pouco ao longo das sucessivas versões do rascunho até que a carta definitiva de resposta à Zasulitich se dê de maneira bem mais sucinta (feita em duas páginas manuscritas, mas que caberia em uma página datilografada). Devido à sua importância histórica, vale a pena reproduzi-la na íntegra:

8 de março de 1881. 41, Maitland Park Road, Londres N.W.

Cara Cidadã: ${ }^{5}$ Um problema de nervos que tem me afetado periodicamente nos últimos dez anos me impediu de responder antes sua carta de 16 de fevereiro. Eu lamento que não possa Ihe dar um texto para publicação sobre a questão que me deu a honra de levantar. Alguns meses atrás, eu prometi um texto sobre o mesmo assunto ao Comitê de São Petersburgo. Mesmo assim, espero que algumas linhas sejam suficientes para tirá-la da dúvida sobre a maneira como a minha chamada teoria foi mal entendida. Analisando a gênese da produção capitalista, eu disse: "No cerne do sistema capitalista está a separação do... produtor dos meios de produção... a expropriação do produtor ruralé a base de todo o processo. Somente na Inglaterra ele foi completado de maneira radical... Mas todos os outros países da Europa Ocidental estão seguindo o mesmo curso." (Capital, edição francesa, p. 315) Portanto, a "inevitabilidade histórica" de tal curso é expressamente restrita aos países da Europa Ocidental. A razão para essa restrição é indicada no cap. XXXII: "A propriedade privada baseada no trabalho pessoal... é suplantada 
pela propriedade privada capitalista, que se baseia na exploração do trabalho de outros, no trabalho assalariado." (loc. cit., p. 340) No caso ocidental, então, uma forma de propriedade privada é transformada em outra forma de propriedade privada. No caso dos camponeses russos, entretanto, sua propriedade comuna/ teria que ser transformada em propriedade privada. Então, a análise em 0 Capita/ não dá argumentos pró ou contra a vitalidade da comuna russa. Mas 0 estudo especial que fiz dela, incluindo pesquisa em material das fontes originais, me convenceu que a comuna é o fulcro para a regeneração social na Rússia. Mas, a fim de que possa preencher essa função, as influências nocivas que a cercam de todos os lados precisam ser eliminadas antes para que ela possa ter asseguradas as condições normais de desenvolvimento espontâneo. Cara cidadã, tenho a honra de permanecer Sinceramente Seu, Karl Marx (MECW, vol. 46, p. 71).

Como vemos, Marx, apesar de manter aberta a porta para um papel positivo da comuna rural, colocava condições para que ela pudesse tê-lo, sem dizer claramente o que achava que ocorreria no futuro. Acredito que o procedimento correto é utilizar essa versão final da carta (mais reservada) do que os rascunhos mais "entusiasmados" (como muitos autores fazem) para ter a posição real de Marx sobre a questão. Afinal, poucos são os escritores que gostariam de expor seus rascunhos de escritos ao público: querem que o público veja a versão final melhorada, bem trabalhada e polida. No rascunho as ideias estão ainda embrionárias, são utilizadas expressões soltas, "recados para si mesmo", etc.: o autor não quer que o público o veja "de pijama" e sim em suas melhores roupas "de sair".

Tanto a carta definitiva corresponde melhor à ideia de Marx sobre o problema, que no penúltimo ano de sua vida (1882) Marx deu uma resposta direta, clara e pública à questão da comuna rural russa quando, conjuntamente com Engels, escreveu o prefácio à segunda edição russa do Manifesto Comunista. No prefácio, os dois escreveram:

A comuna rural russa, mesmo sendo uma forma muito minada da antiga propriedade comum da terra, pode passar diretamente à forma superior comunista de propriedade comum? Ou, ao contrário, precisa antes passar pelo mesmo processo de dissolução que constituiu a evolução histórica do Ocidente? A única resposta possível hoje é a seguinte: se a revolução russa se tornar um sinal para a revolução proletária no Ocidente, de modo que as duas se complementem, então a presente propriedade comum da terra na Rússia pode servir de ponto de partida para um desenvolvimento comunista (MEW, vol. 19, p. 296; cf. Sochineniya, vol. 19, p. 305).

Essa pode ser considerada a posição final de Marx sobre a questão (já que ele morreria logo depois). "Se... pode..." é a fórmula condicional de Marx. Inclusive devemos tomar cuidado com as traduções. Em português, muitas vezes a frase final da citação acima é traduzida como "a presente propriedade comum da terra na Rússia SERVIRÁ de ponto de partida...". Essa tradução é errônea. Tanto o original alemão redigido por Marx e Engels quanto a versão 
final russa impressa do prefácio da segunda edição do Manifesto Comunista na Rússia usam claramente a expressão "pode servir" em vez do mais decidido "servirá" (como mostrado na indicação das duas fontes primárias alternativas do trecho acima).

\section{Conclusão}

visão de Marx sobre as possibilidades revolucionárias na Rússia passou por duas
etapas, bem diferentes entre o início e o fim, com uma longa fase de transição entre elas. Desde sua "conversão" ao comunismo em 1844 em Paris até o imediato Pós-Guerra da Crimeia de 1853-1856, Marx tinha uma visão extremamente negativa da Rússia, como o bastião da reação e da contrarrevolução. Depois disso, uma lenta fase de transição de uns dez anos teve início. Primeiramente, as agitações na Rússia nos anos que precederam a abolição da servidão em 1861 abriram os olhos de Marx para a possibilidade de que algum tipo de abalo social atingisse o país (revolta camponesa de baixo? revolução burguesa por cima?). Nesses anos pré-abolição, Marx, apesar de continuar com a visão das classes dominantes da Rússia como a fortaleza da reação, concomitantemente abriu, por um tempo, a possibilidade de acontecimentos revolucionários na Rússia. Como esses abalos não se concretizaram, na "calma" (i.e., não revolucionária) década de1860, Marx retomou sua visão tradicional da Rússia como fortaleza da reação. Outro momento dessa fase de transição foi a partir de 1868, quando a tradução para o russo do volume 1 de 0 Capital colocou Marx em correspondência direta com revolucionários e pensadores russos, o fez estudar o idioma russo e passar a estudar a Rússia "de dentro", através das fontes primárias russas na língua original. Finalmente, na década de 1870, após o fracasso da Comuna de Paris de 1871 confirmar as derrotas anteriores das revoluções de 1848, e o Ocidente não parecer ter a revolução no horizonte, Marx voltou-se ainda mais para a Rússia, investigando se seu peculiar regime social (um país que agora abolira a servidão e ingressara na via capitalista, mas mantendo a instituição da comuna rural) poderia servir como base para futuros desenvolvimentos revolucionários comunistas.

Os últimos textos de Marx se prestaram a diversos tipos de interpretação. Desde que a revolução comunista seria possível começando na Rússia, passando por posições de que a Rússia poderia iniciar a revolução, mas para completá-la precisaria que ela se espalhasse pelos países capitalistas mais avançados do Ocidente. Ou até que a ideia de que a comuna rural poderia servir de base para desenvolvimentos socialistas era mesmo irrealista, pois a comuna realmente estava sendo minada pelo desenvolvimento capitalista (depois da morte de Marx, com o tempo, Engels tendeu para tal ponto de vista, no final da vida). ${ }^{6}$ 
A visão do presente autor é que a posição final de Marx ficou definida no prefácio da segunda edição russa do Manifesto Comunista. Se a revolução na Rússia se ligasse a outras revoluções nos países capitalistas mais avançados, a comuna rural poderia servir de ponto de apoio para futuros desenvolvimentos em direção ao comunismo. Mas isso não era dado e dependeria de outros fatores, como Marx colocou na sua última frase na carta de resposta a Vera Zasulitch.

De qualquer modo, há exatamente cem anos a História mostrou o tipo de revolução possível, concretamente, na Rússia.

\section{NotAS}

1 "Mouro" (devido a sua tez morena) era o apelido de Marx em sua idade adulta entre amigos e família nuclear.

2 Em relação ao fato de que a constatação pelos russos, durante a Guerra da Crimeia, de seu atraso tecnológico em relação aos superiores armamentos e equipamentos ingleses e franceses levara a reformas no país (que culminariam na abolição da servidão), em carta a Engels de 13 de dezembro de 1859, Marx comentaria que "[Na] Rússia o movimento está se desenvolvendo mais rápido que no resto da Europa [...] Quando a próxima revolução eclodir, a Rússia gentilmente se revolucionará também" (MEW, vol. 29, p. 525).

30 Capita/ foi publicado em primeira edição em alemão em 1867, em russo em 1772, em francês em 1885, em espanhol em 1886 e em inglês em 1887. 0 maior interesse imediato pela obra na Rússia pode ser visto pelo fato de que a edição russa vendeu os primeiros mil exemplares em pouco menos de dois meses, enquanto a edição alemã original levou cinco anos para atingir a marca de mil exemplares vendidos (MEW, vol 33, p. 492). Marx, consciente disso, comentou em uma carta a Friedrich Sorge de 5 de novembro de 1880 que: "Na Rússia, onde O Capitalé mais lido e apreciado que em qualquer outra parte, nosso êxito é ainda maior" (MEW, vol. 34, p. 477).

4 Em carta a Sigfrid Meyer de 21 de janeiro de 1871, Marx escreveu: "Não sei se lhe disse, mas desde 0 começo de 1870 eu mesmo passei a estudar russo, língua que agora leio bastante fluentemente" (MEW, vol. 33, p. 173).

5 Cidadão era a maneira como os revolucionários se tratavam no século XIX (herança da Revolução Francesa que consagrou a expressão (itoyens!), equivalente ao camarada do século XX nos países socialistas.

6 Para esta visão mais crítica final de Engels sobre a comuna rural russa, ver, por exemplo, sua carta a Nikolai Danielson de 17 de outubro de 1893 (MEW, vol. 39, p. 148-150).

\section{REFERÊNCIAS BIBLIOGRÁFICAS}

Karl Marx Friedrich Enge/s Werke. Berlin: Dietz Verlag, 1956-1977. 43 vols. (MEW)

Marx-Engels Collected Works. London: Lawrence \& Wishart, 1975-2004. 50 vols. (MECW)

Sochineniya - K. Marks, F. Engels Sochineniya. 2a ed. Moscou: Izdatel'stvo Politicheskoi Literatury, 1955-1974. 50 vols. 